University of Nebraska - Lincoln

DigitalCommons@University of Nebraska - Lincoln

Faculty Publications, Department of History

History, Department of

December 1996

\title{
Making Savages of Us All: White Women, Pueblo Indians, and the Controversy over Indian Dances in the 1920s
}

Margaret D. Jacobs

University of Nebraska - Lincoln, mjacobs3@unl.edu

Follow this and additional works at: https://digitalcommons.unl.edu/historyfacpub

Part of the History Commons

Jacobs, Margaret D., "Making Savages of Us All: White Women, Pueblo Indians, and the Controversy over Indian Dances in the 1920s" (1996). Faculty Publications, Department of History. 17.

https://digitalcommons.unl.edu/historyfacpub/17

This Article is brought to you for free and open access by the History, Department of at DigitalCommons@University of Nebraska - Lincoln. It has been accepted for inclusion in Faculty Publications, Department of History by an authorized administrator of DigitalCommons@University of Nebraska - Lincoln. 
Margaret D. Jacobs

\section{Making Savages of Us All: White Women, Pueblo Indians, and the Controversy over Indian Dances in the 1920s}

In 1920, as part of an extensive effort to gather information about the rumored immorality of Pueblo dances, an inspector from the U.S. government took sworn affidavits and written statements from about a dozen Hopi Indians and seven white observers. In one of the statements, witness Evelyn Bentley, a field matron on the Hopi Indian Reservation in Oraibi, Arizona, described the scene below:

Two clowns dressed as women came into the court. Their skirts were very short, not over eleven inches long. The men clowns would go up to them and try to pull the skirts down a little. The clowns who stood behind the women would try to pull the skirts down in the back but while doing so the skirts would slip up in front. Then the clowns who stood in front would stoop down and look up under the skirt as if looking at a woman's private organs. Then the other clowns would come around and have a look, then all would make believe that they were trying to pull the skirts down, then stoop and look under to see how much they could see. All this brought forth much laughter and many yells from the crowd. ${ }^{\mathrm{I}}$

Other witnesses testified that the clowns simulated sexual intercourse with Indian women or livestock and enacted skits depicting adultery, prostitution, and divorce. Reformers and Bureau of Indian Affairs (BIA) employees gathered about two hundred pages of this testimony into what became known in Indian reform circles as the Secret Dance File. Because reformers considered the Secret Dance File too obscene to print or to send by mail, they "confidentially passed [it] from hand to hand for two years," and a great chain of gossip developed regarding its contents. ${ }^{2}$

The Secret Dance File proved to be more than a source of shock and fascination to Indian reformers. It served as one of the major factors in I92I that

Copyright $(9) 1996$ by Frontiers Editorial Collective 
led Commissioner of Indian Affairs Charles Burke to sign Circular 1665, an order to all BIA superintendents that threatened to ban Indian dances that involved "immoral relations between the sexes" and "any disorderly or plainly excessive performance that promotes superstitious cruelty, licentiousness, idleness, danger to health, and shiftless indifference to family welfare."3 In 1923, Burke issued a supplement to the circular that endorsed six recommendations made by a 1922 conference of missionaries. Concerned that Indians should adopt white conceptions of thrift and agricultural production, these recommendations prohibited give-aways, banned all dances between March and August, and forbade anyone under fifty from dancing. They also limited dances to one a month in the daylight hours on a day in midweek at one center in each district. Hoping to use moral influence, Burke's supplement called for a year's trial to determine if the Indians would voluntarily give up the "worst features" of their dances and threatened to "take some other course" of action if the Indians did not. ${ }^{4}$

When word of the Secret Dance File and of Burke's circular and supplement reached the newly formed Indian advocacy organizations of the 1920s, they quickly adopted a position in opposition to what writer Mary Austin called the "Bumbletonian Indian Bureau's" circular. ${ }^{5}$ Disillusioned by World War I and disheartened by the modernization of America, many members of these new groups had "discovered" the Pueblos as the antidote to the ills of modern America. Together with the All Pueblo Council, they had successfully organized a nationwide campaign to defeat the Bursum Bill, legislation that they believed would have led to the Pueblos losing much of their land to surrounding Anglos, Hispanos, and Mexicans. In the ra2os, their efforts led to the elevation of the Pueblos as the signature Indian in the white imagination, taking the place, temporarily, of Plains Indians. A stormy controversy ensued between defenders of Pueblo dances, both native and white, and a group of reformers, BIA employees, and Pueblo Indians who favored a ban on many Pueblo dances.

Historians who have covered the dance controversy usually treat it just in passing as one of the events in John Collier's reform career before he became Franklin Roosevelt's Commissioner of Indian Affairs. They have generally characterized the public debate over Indian dances as a struggle over whether religious freedom should be extended to Native Americans. ${ }^{6}$ To many Native Americans, the threat to ban Indian dances certainly did impinge on their religious practices. Yet, the controversy itself involved more than a constitutional debate on religious freedom. Many of the non-Indian participants in the controversy were white women who, in an era in which gender roles and female sexuality were in flux, used the controversy to voice their anxieties, their hopes, and their visions regarding new roles and sexual standards. In their discourse 
regarding Indian dances, these white women revealed a greater concern with emerging sexual mores in American society at large than with the traditional religious practices of Native Americans. From 1900 to 1930, a conflict ensued between two groups of feminists over the issue of sexuality. One group-female moral reformers - sought to maintain female purity and exert moral authority, while another group - "new feminists" - argued for women's self-fulfillment and expression of sexual desire. ${ }^{7}$ Their debate on changing social and cultural mores did not always take place openly or consciously; often it showed up in arenas in which gender and sex were not explicitly being discussed. ${ }^{8}$ In the controversy over Indian dances, female moral reformers tended to view Pueblo dances as symbols of sexual disorder that must be curbed. "New feminists" lauded these same dances as emblems of sexual liberation that should be preserved.

Pueblo men in the debate rejected both of these views of their dances and their culture. Instead, they highlighted a multitude of other interests, centered around land and water rights, deepening economic dependence on non-Indians, and the intrusions of new Protestant missionaries, government bureaucrats, anthropologists, writers, and artists. Their participation in the dance controversy reflected their own quest to come to terms with Mexican and white expansion into both their physical territory and their cultural arenas. To the Pueblos, the perpetuation or elimination of traditional dances represented competing approaches to coping with new economic, social, and cultural forces.

Interestingly, Pueblo women became powerful symbols for all sides in the dance controversy. White women who debated Indian dances, depending on their orientation toward changes occurring in white society, invested Pueblo women with either their greatest fears of sexual degeneration or their greatest hopes for sexual liberation. Pueblo men on both sides of the debate insisted on Pueblo women's modesty. They divided, however, on the role Pueblo women should play in the work of their villages and in the future of their pueblos. Due to the Pueblo custom that only certain men, chosen by the religious hierarchy, should represent their pueblos to outsiders, no evidence of Pueblo women's direct participation in the dance controversy surfaces in the written record. Nevertheless, autobiographies by two Hopi women provide clues as to how Pueblo women viewed themselves in relation to their symbolic roles. ${ }^{9}$

Beginning in the late 1870 , some middle-class Protestant white women had taken an active interest in reforming federal Indian policy. Inspired by a Ponca chief who toured eastern cities to relate the tragedy of Ponca removal, two veteran reformers, Mary Bonney and Amelia Stone Quinton, established the Women's National Indian Association (WNIA) in 1879. In I88I, the publication 
of Helen Hunt Jackson's A Century of Dishonor, which documented atrocities committed against Native Americans, nourished the new reform movement. (Male reformers founded the Indian Rights Association [IRA] in I882.) These reformers believed that the resolution of the "Indian problem" could be achieved only if Native Americans became fully assimilated into mainstream American society. As one reformer, Mary Dissette, phrased it, "the greatest wrong the Indian has suffered at our hands has been his separation from our own social and national life." ${ }^{\circ}$ Reformers designated a special role for white women to play in the process of assimilating Native Americans: "uplifting" supposedly degraded Indian women and transforming their pagan households into Christian homes. ${ }^{\text {II }}$

Taking its cue from this new, vocal, and influential group of reformers, the BIA crafted a policy designed to accelerate the progress of Indians toward "civilization." In the late nineteenth century, Congress passed the Dawes Act, which called for the allotment of communally held Indian lands to individual Indians, and established twenty-five off-reservation boarding schools as well as dozens of on-reservation boarding schools and day schools for Indians around the nation. ${ }^{12}$ Institutionalizing the WNIA's notion of "women's work for women," the BIA hired many white women as schoolteachers and initiated a field matron program "in order that Indian women may be influenced in their home life and duties, and may have done for them in their sphere what farmers and mechanics are supposed to do for Indian men in their sphere."I3

Mary Dissette and Clara True, two of the most vociferous opponents of Pueblo Indian dances in the I920s, had taken up the call for women's work for women among the Indians. In I888, the Presbyterian Board of Home Missions had sent Dissette to work to convert and civilize the Indians at Zuni Pueblo. She stayed at Zuni for almost twelve years, serving first as the Presbyterian mission schoolteacher, then as superintendent of its Zuni Industrial School, then as a BIA schoolteacher, later as a nurse during the smallpox epidemic of 1898 to 1899, and finally as a field matron. ${ }^{14}$ For the next thirty years, Dissette worked in various aspects of Indian education, teaching at Paguate Day School near Laguna Pueblo and at Santo Domingo Pueblo in the I9ros, serving as a librarian at the Santa Fe Indian School in the I920s, and then working at Chilocco Indian School in Oklahoma before returning to live in Santa Fe. ${ }^{15}$ During the course of her career in Indian work, Dissette befriended True, another female reformer. True became involved in Indian reform work in the I890s when she served six years as principal of the boarding school at the Lower Brule Agency on the Sioux Reservation. From 1902 to 1907 , True worked as the school teacher at the Santa Clara Pueblo day school, and in 1908 she became the superintendent of 
the Mission Indians at the Morongo Reservation near Banning in southern California. Around I9IO, she returned to New Mexico to settle in the Espanola Valley, close to Santa Clara Pueblo. Here she owned and operated a series of ranches and managed an apple, hay, and livestock business. ${ }^{16}$ From 1910 until the I940s, although True did not work in an official capacity with the Santa Clara Indians, she involved herself intensely in their affairs.

White women who became interested in Indian reform at this time usually had roots in other women's reform activities. Mary Bonney had founded the Chestnut Street Female Seminary in Philadelphia, had served as an active member of the Woman's Union Missionary Society of Americans for Heathen Lands, and had held the presidency of the Women's Home Mission Circle. Amelia Stone Quinton had equally impressive reform credentials; she had worked in asylums, almshouses, infirmaries, prisons, and women's reformatories and had been a state organizer for the Woman's Christian Temperance Union. ${ }^{17}$ Dissette and True also had significant connections to other middle-class female moral reform. For example, in the I9IOs, as members of the WCTU, they joined forces to crusade against vice and corruption within the BIA. ${ }^{18}$

Before 1915, Dissette and True and other reformers among the Pueblos seemed to have taken little interest in Pueblo dances. Until that time, reformers' discussions of Indian dances had centered more on the dances of the Plains Indians. The BIA worried that Indian dances promoted "savagery" and warlike behavior and prevented the Indians from becoming more industrious. In I883, the BIA compiled a "List of Indian Offenses," aimed at eradicating the Ghost Dance, the Sun Dance, give-aways, and other ceremonies that it believed led the Indians to be more warlike and less industrious. ${ }^{19}$ The government virtually took no notice of Pueblo dances before 1915. In 1913, a lengthy report on the Pueblos contained nothing about their dances at all. ${ }^{20}$

In I915, however, P. T. Lonergan, Superintendent of the Pueblo day schools, submitted a report to the BIA entitled "Immoral Dances Among the Pueblo Indians." His report would later be incorporated into the "Secret Dance File." Lonergan asserted that the dances the Pueblos held in secret were "grossly immoral" and that "some of the most disgusting practices are indulged in, the particulars being so bestial as to prohibit their description." To substantiate his claims, Lonergan included six letters from whites and Mexicans "living in the vicinity of the Indians." 21 The complaints regarding Pueblo dances and culture did not emanate only from white observers. Some New Mexico Pueblo Indians contacted BIA officials to alert them to their displeasure at having to perform the dances. ${ }^{22}$ Several Hopis contributed their testimony to the Secret Dance File.

Despite these first signs that some whites and Indians found Pueblo dances problematic, it was not until the I920s that an organized campaign against the 
dances occurred. In the meantime, female moral reformers focused on the BIA rather than Pueblo Indians as a hotbed of corruption and immorality. Even as Lonergan began his assault on what he deemed "grossly immoral practices among the Pueblo Indians," he and other BIA employees had become the subjects of an attack by True and Dissette. Alleging that several BIA employees under Lonergan's supervision had engaged in extramarital affairs, that Lonergan's assistant had contracted venereal disease, and that Lonergan himself visited houses of prostitution, True and Dissette waged a campaign to have Lonergan and other BIA employees removed from their positions. ${ }^{23}$ In the early I920s, the issue of Pueblo dances suddenly became more pronounced when the BIA sent Inspector E. M. Sweet to gather testimony regarding the alleged sexual immorality of Hopi dances. Dissette and True turned their crusade against sexual immorality toward the Pueblo Indians, finding in their traditional dances gross obscenity and debauchery. A furor built among reformers to condemn and restrict the secret dances of the Pueblo Indians. ${ }^{24}$ Reformers saw their efforts come to fruition in 192I when Commissioner of Indian Affairs Burke issued Circular I665.

Circular 1665 and its supplement bear the particular mark of female moral reformers. The circular condemned dances that led Indians to neglect their "home interests" and promoted "shiftless indifference to family welfare." It recommended "fixing the standards of individual virtue and social purity that should prevail in all forms of amusement or symbolism" and inculcating "a higher conception of home and family life." ${ }^{25}$ As Peggy Pascoe has analyzed, such rhetoric was ubiquitous among female moral reformers of the late nineteenth and early twentieth centuries. ${ }^{26}$ The circular also promoted alternatives to dances- "something in the way of wholesome, educational entertainment that will tend to divert interest from objectionable native customs." ${ }^{27}$ Urban progressive reformers similarly attempted to provide working-class women with wholesome substitutes for jazz dancing. ${ }^{28}$ Indeed, the language of the circular paralleled the rhetoric used by reformers who thought that jazz dancing incited idleness and dissipation among American youth. ${ }^{29}$

Reformers justified their campaign to eradicate Indian dances based on the testimony found in the Secret Dance File. The performances of ritual clowns in the Pueblos' dances elicited particular condemnation from female moral reformers. Although Pueblo dances were solemn occasions in which the participants prayed for rain, a fertile and abundant crop, or a successful hunt, the dances also involved intermittent interruptions by a group of clowns. Moral reformers found the clowns' antics obscene. Field matron Bentley's description of the Hopi clowns' skit, in which they peeked up women's dresses, epitomized the vulgarity of Indian dances to moral reformers. Some Hopi converts to 
Christianity also testified that the practices of the clowns were sexually immoral. Hopi witness Johnson Tuwaletstiwa described a scene in a dance in which two katsinas, male masked impersonators of supernatural beings, pretended to work in their fields in front of the clowns. ${ }^{30}$ In this scene, one katsina was dressed as a woman and one as a man:

The clowns pretended not to see them. These two katsinas at length pretended to grow tired of their work, and went over to a place representing their booth and rested. Then, while the whole crowd of spectators were looking on, men, women and children, the katsina man took hold of the katsina woman and went through the performance of the act of cohabitation. Upon its conclusion the clowns turned and appeared to discover them, and asked what they were doing, to which, feigning shame, they made no reply. Thereupon one of the clowns approached the katsina woman and solicited her to do the same act with him. This led to a quarrel between the katsina husband and wife, ending in the wife discarding her husband, who walked around the street feigning weeping and lamentation because he was thus divorced after the Hopi manner... Thereupon one and each and all the clowns severally, five in all, went through the act of cohabitation with the katsina woman successively. ... The whole scene was a dramatization of the act of Hopi life depicting adultery and prostitution; the crowd meanwhile laughing and apparently approving and enjoying it as a dramatic representation of Hopi life. ${ }^{3 \mathrm{I}}$

As Tuwaletstiwa expressed here, reformers and some Hopi witnesses believed the performances of the clowns to be actual representations of everyday Pueblo life. However, as we shall see, the clowns often performed antics deemed inappropriate by Pueblo Indians.

Reformers also charged that the dances served as occasions for unbridled sexual license, promoting premarital and extramarital sex and encouraging divorce. One Hopi witness, Kuwanwikvaya, asserted that, at Hopi dances, "young unmarried men and women ... commit fornication, and the married ones commit adultery." 32 Another Hopi witness recalled "six women ... who have had five or six husbands, discarding one for another, and nearly always at these dances or growing out of these dances." 33 Reformers and their Hopi informers also expressed alarm that "sex subjects and sex functions are the subjects of common conversation between [Hopi] men and women, boys and girls, in the home, anywhere, without restraint." Again, reformers and their witnesses blamed the dances for cultivating this atmosphere. ${ }^{34}$

Opponents of Pueblo dances also were appalled that Indian women, as they were impersonated by male clowns in the dances, appeared to be active sexual beings. Tuwaletstiwa expressed his disgust at a Hopi dance in which two 
clowns went through the motions of sexual intercourse. He remarked that "the conclusion of the scene was that the man got up and went leaping and singing happily and thus disappeared, while the woman [clown], more quietly but with expressions indicating happiness, also disappeared." 35 As portrayed by male clowns and as represented in the Secret Dance File, Indian women seemed to be active partners, not passive victims, in adulterous relationships and in fornication. This challenged female reformers' views of Indian women as the innocent victims of Indian male lust and BIA corruption. ${ }^{36}$

In the I920s, female moral reformers uneasily combined this new view of Indian women with their older notions. In a 1924 letter, Dissette complained that in Pueblo cultures, "the male is supreme and all that contributes to his comfort or pleasure is his by right of his male supremacy." ${ }^{7}$ However, in the same letter, Dissette also alleged that Indian women actively engaged in the sexual practices she deplored. She accused older women at Santo Domingo Pueblo of "instructing young girls in sex matters one of which was 'manipulating the penis'" during a ceremony. ${ }^{38}$ This conflicted depiction of Indian women mirrored the new conceptions of white womanhood put forward by moral reformers in the 1920 in which, as one historian explains, "the proverbial dark lady and fair maiden were fusing into the same woman." 39

Though reformers such as Dissette and True had worked with the Pueblos since 1888 and 1902 respectively, neither seemed to express any concern about Pueblo sexual morality until after 1915. As changing sexual mores in white American society became a topic of great controversy in the I9IOs and I920s, moral reformers suddenly discovered rampant sexual immorality among the Pueblos. Moral reformers' usage and condemnation of concepts current in white debates reveals the extent to which they projected their concerns about white sexual mores onto Pueblo Indians. One Hopi witness claimed that all through the Snake Dance, "men and boys and women and girls mingle freely together-there is 'free love." "40 Dissette condemned the supposed ease of divorce among the Zunis as "trial marriage." Notions of "free love" and "trial marriage" gained wide exposure and censure in popular magazines in the first three decades of the twentieth century. ${ }^{4 I}$

Reformers' concerns about Pueblo dances - that they encouraged promiscuity, adultery, and divorce, and that they led to more open discussions of sexuality and an active sexual role for women - masked their anxiety over these very trends in white society. Between 1867 and I929, the divorce rate among Americans had escalated 2000 percent, and by the end of the 1920 one in six marriages ended in divorce. Such statistics upset many moral reformers and social critics, who feared that divorce imperiled women. ${ }^{42}$ More frequent discussions of sexuality in white American society disturbed moral reformers as well. Ironi- 
cally, their campaigns against venereal disease and prostitution had actually expanded the public discourse on sexuality. ${ }^{43}$ At the same time that moral reformers came to "sexualize" Indian women, they had also begun to allow, with dismay, that white women, too, could be sexual agents. Whereas Victorian female moral reformers blamed male lust for fallen women, I920s moral reformers raised the specter of "the girl vamp" who corrupted young men. ${ }^{44}$ They worried that young white women's newfound expectation for sexual satisfaction was likely to lead to "a pagan attitude toward love itself." 45 In the minds of female reformers, Indian women, became, in essence, "new women." Reformers blamed dances in white society as well as in Pueblo culture for corrupting morals. Some commentators even drew connections between Indian dances and the new jazz dances. As one critic put it, "One touch of jazz makes savages of us all." 46

Reformers' efforts to enforce Victorian moral codes in white American society seemed to have little effect on preventing what they believed to be rampant social disorder. While ostensibly condemning the supposedly free and easy sexual customs among Pueblo Indians, moral reformers gave voice, in reality, to their anxieties over the social disorder they believed would result from changes in white sexual mores. If this disorder and sexual immorality could be distanced from white culture and located within a "primitive" culture, perhaps it could be properly contained.

Not all white Americans or Pueblo Indians agreed, however, that Pueblo dances were immoral and should be banned. The new group of activists who admired and championed Pueblo culture reacted to the charges of the Secret Dance File in numerous ways. Some activists defended Indian dances based on what might be called an equal rights doctrine. Stella Atwood, founder and chair of the Indian Welfare Committee of the General Federation of Women's Clubs (GFWC), contended that "the Constitution of the United States guarantees religious liberty, [and] the treaty of Guadalupe Hidalgo asserted that none of [the Pueblo Indians'] religious ceremonies or religious life could be interfered with." 47 Another group of dance preservationists argued against the circular on the grounds that it would destroy a valuable part of America's cultural treasure. One of the new I920s Indian advocacy groups, the American Indian Defense Association (AIDA), characterized the circular as part of the government's efforts to destroy "an incalculable wealth of folklore, of beautiful customs and arts and moral values." ${ }^{8}$ Many white women who defended Pueblo dances developed what might be called a "sexually relativist" position in defense of the dances. In the first decades of the twentieth century, these women had begun to shape a new kind of feminism that extolled rather than denied women's "sex 
expressiveness," called for women's individual self-fulfillment rather than selfsacrifice, and challenged women's quest for moral authority. These new feminists found much to admire, rather than vilify, in Pueblo dances.

To these new feminists, Pueblo ritual clowns did not appear sexually immoral. Writer Erna Fergusson asserted that some of the clowns' sexual acts served as fertility rites, since their "prayers for rain often include appeals for all life, animal and human as well as plant." 49 Writer Mary Austin asserted that "the social function of the [clowns] is to keep the community in order, with whips of laughter. These humorous interludes often take the form of dramatic skits based upon the weakness or the misadventures of the villagers." 50 New feminists had adopted what would become some of the standard anthropological explanations for the clowns' performances. Anthropologist Alfonso Ortiz explains that one function of the clowns' sexual lampoons, particularly those involving phallic jokes, is "intended for ... cosmic regeneration and renewal." Furthermore, some anthropologists have argued that the clowns could also serve to regulate community behavior by making fun of inappropriate actions. As anthropologist Vera Laski put it, "by discussing, publicly and jokingly, the most recent village gossip, especially that related to sex matters-ridiculing adultery and airing the gossip as to who sleeps with whom-they are the friendliest, gayest, and best liked moral squad any community ever had." ${ }^{1}$

New feminists of the I920s also added another layer of meaning to the clowns and the dances that extolled Pueblo sexuality as "more natural" than white American sexuality. Austin revered the Hopis as a culture "where procreation is still associated with worship." 52 Fergusson declared that "to an Indian, human generation is no more obscene than is the fertilization and development of a plant." 53 In lauding the "natural" sexuality the clowns supposedly expressed, new feminists seemed to thumb their noses at the moral reformers' standards of acceptable sexuality. They also rejected moral reformers' condemnation of easy divorce. Anthropologist Elsie Clews Parsons (who advocated "trial marriage" in her 1906 book, The Family) marveled that Zuni women owned their houses and gardens and that their husbands joined the wife's household. "He stays in it, too, only as long as he is welcome," Parsons wrote. "If he is lazy, if he fails to bring in wood, if he fails to contribute the produce of his fields, or if some one else for some other reason is preferred, his wife expects him to leave her household. He does not wait to be told twice." 54

Unlike moral reformers, new feminists conceived of Indian women as dignified and strong figures who played prominent roles in Pueblo culture. Fergusson's description of Indian women's part in the Deer-Dance at Taos captures this view of Pueblo women: 
Two women lead.... In one hand each woman carries pine twigs, in the other a gourd. At certain points in the dance each woman moves slowly down the line of waiting men, making sharp peremptory motions with the gourd. As she does this, each man drops to his knees. Returning, she makes a reverse gesture and the men rise. This perhaps typifies the call of the universal spirit of fertility, the usual significance of a woman figure in the Indian dances. They are treated with reverence, and during this figure the nonsense and the thieving of the [clowns] are stopped.55

New feminists' celebration of Pueblo women challenged reformers' notions that Indian women were either passive victims or active leaders in sexual immorality.

Like moral reformers, however, new feminists used the Pueblos to articulate their views on changing sexual mores in white society. They sometimes even invented a reflection of themselves within Pueblo cultures, as for example when Parsons concluded that a Zuni woman who dressed and acted as a man was a "strong-minded woman, a Zuni 'new woman,' a large part of her male." ${ }^{6}$ Much like the moral reformers, in fact, new feminists envisioned Pueblo women as "new women." In their eyes, however, this merited admiration, not contempt.

Much as they often lauded new "sex expressiveness" for women, new feminists also harbored doubts about emerging sexual mores. They often conveyed a sense that women had lost control of their sexuality. For example when writer Mabel Dodge Luhan's lover (and later her third husband), Maurice Sterne, pressured her to have sex, Luhan wrote, "I felt very weary and emancipated. When he argued that it would interfere with his Work if I didn't let him make love to me, that old persuasion convinced me that I might as well be hospitable to him without stint and not be narrow-minded." 57 What Luhan and other new feminists had come up against was an unintended consequence of the new standards they helped to create. As other historians have noted, in the I920s and beyond, women were not just allowed to be sexually expressive, they were required to be. Women who held back sexually risked being labeled as sexually repressed. As Christina Simmons and Estelle Freedman have argued, Victorian sexual standards had given precedence to women's control of sexual relationships. New sexual standards divested women of this control, "cast women as villains if they refused to respond to" male sexuality, and increased men's power in sexual relationships. ${ }^{5}$

When they set out to defend the Pueblos' dances on sexually relativist grounds, new feminists inevitably confronted their own ambivalence about emerging white sexual standards. This surfaced in some of their portrayals of Pueblo women. For instance, when Luhan acquired a shawl like those Pueblo women wore, she noted, "the Indian women are sheltered in their shawls, seeming so comfortable and encompassed within them, so that their whole being 
was contained, not escaping to be wasted in the air, but held close and protected from encroachments. How exposed we live, I thought, so revealed and open! I longed for the insulation of the shawl and wore mine whenever I could." 59 New feminists represented Pueblo women as sexually expressive on the one hand and as modest and protective of their sexuality on the other. The Pueblo woman came to embody new feminists' desires for both a healthy "sex expressiveness" and for women's control over their sexuality.

Ambivalence led many new feminists to retreat from a sexually relativist defense of the dances. Although they often questioned moral reformers' sexual standards, at other times new feminists accepted the terms of moral reformers and merely denied that the Pueblos were sexually immoral. In the most striking illustration of this tendency, Luhan maintained that the Pueblos lead a

well balanced, natural and usual sex life ... in their family life.... They never think sex-or talksex. They all seem to be horrified at bringing it into speech, letter, and discussion as [the moral reformers] are doing here-they are ashamed to think "their pueblo" could come under any such consideration. They have a strong natural modesty always. I have never seen a sign of sex exhibitionism in an Indian. They are . . the purest people I know. ${ }^{60}$

Here Luhan seemed to equate terms describing the new sexuality she championed - "well balanced, natural and usual" - with notions of "modesty" and "purity" that moral reformers had long revered. Increasingly, rather than espousing a "sexually relativist" argument, new feminists came to defend the dances on the moral reformers' terms.

The Indian dance controversy climaxed, as it were, in 1924 at the General Federation of Women's Clubs (GFWC) Biennial Convention in Los Angeles. The GFWC's Indian Welfare Committee and its dynamic chairperson, Stella Atwood, had been instrumental in preventing the passage of the Bursum Bill. In 1924, Atwood hoped to place a resolution before the GFWC that would challenge the BIA's attempt to eliminate Indian dances by upholding the Indians' rights to religious freedom. But other women, led by True, crashed the convention. True organized a delegation of reformers and Pueblo Indians who opposed the dances to go to the "Christian women of the convention with a protest against the program of paganism . . . approved by Atwood." BIA Inspector and prominent Hispana civic leader Adelina "Nina" Otero-Warren accompanied True. ${ }^{61}$ When True arrived in Los Angeles, she sized up the crowd of eight thousand women and decided it to be "nearly solidly hostile." She realized "we had to convert them." After much behind-the-scenes organizing, True succeeded in getting ten minutes on the program to make her case. During their 
allotted time, first Otero-Warren made an appeal to the "Christian women of America." Then Ida May Adams, a member of the Indian Welfare League of California, spoke on behalf of the Pueblo Indians who opposed Indian dances. Adams asked the Indians to stand and they "received vigorous applause." Then, according to True, "everybody knew there was a big fight on right then and there. It was no longer a one-sided game with . . . the pagan issue getting all the support. There was a FIGHT on." 62

In the meantime, hearing of True's planned attack, Atwood and her supporters had organized their own campaign to convince the women delegates of the need to preserve Indian dances. They brought in their own set of Indians to accompany them on stage and to attest to the beauty and dignity of Indian dances and religion. Charles Lummis, a renowned Southwestern writer and magazine editor, had penned a pamphlet in defense of the dances to be distributed at the door of the convention. Interestingly, the new feminists and their view of Pueblo dances as expressions of natural sexuality were all but invisible at this meeting. Lummis's pamphlet in support of the dances appealed to the GFWC women in the terms of the moral reformers. He argued that the GFWC must support Indian religion because "for milleniums" it "has made good husbands and good wives, good fathers and good mothers, obedient and filial children, good neighbors, and good citizens of that tiny Republic. The result of destroying that Faith would be to destroy that home life which no longer has general parallels among ourselves." Lummis further asserted that "no Pueblo dance was ever so provocative, so suggestive or so demoralizing as many-I fear I should say the majority - of the dances which our boys and girls witness and take part in." ${ }^{63}$ In this setting, the sexually relativist argument of new feminists would not do. Here, it was necessary to appeal to the GFWC women on the grounds that since "Home" and "Religion" were rapidly disappearing in white culture, that where they still existed, in Indian culture, they must be preserved. In Lummis's pamphlet, the Pueblos became not harbingers of a modern sexuality and a new gender order, but emblems of a premodern life where "Home" and "Religion" still mattered. In fact, Lummis and many other defenders of Indian dances extolled Pueblo culture as neither a symbol of sexual degeneracy nor sexual liberation, but as the last bastion of social order.

Despite their differences, both the whites who opposed and the whites who defended Pueblo dances shared many similar assumptions. Each faction believed that one group of Indians represented the "authentic" contingency of the Pueblos. Each side also believed their Indians to be passive victims for whom they could speak. Moral reformers portrayed their Indians both as the victims of a tradition-bound, virtual dictatorship of Pueblo officials and of 
romantic propagandists who wanted to preserve Indians in their "backward" state for the benefit of science and art. ${ }^{64}$ The new activists characterized their "authentic" Pueblo Indians as inheritors of an ancient and beautiful religious tradition who were being victimized by over-zealous moral reformers and a misguided Indian Bureau. ${ }^{65}$ As at the GFWC meeting in Los Angeles, each faction of white activists often brought their group of representative Indians to white audiences to illustrate their case. On many of these occasions, Indians did not speak but seemed to serve only as props for their white advocates.

But Pueblo Indians did not accept their role as the ventriloquist's dummy and sought to redefine the terms of debate. Both those Indians who opposed and those who defended Indian dances sought to make their voices audible above the din of white debaters. During an All-Pueblo Council meeting in 1926, Pablo Abeita of Isleta Pueblo expressed frustration that whites left Indians out of debates about Indian matters. "They say: 'The Indians want this and the Indians want that," he observed of the recent hearings in Washington. "No Indian knows about it. They simply go ahead telling what they think the Indian wants. They ought to call the Indians there and ask what they want. It is not necessary to give him all he wants but it is necessary to listen to him.... We ought to have a voice." 66

If female moral reformers and new feminists had listened to the Pueblos, they would have heard many voices. From those Indians who contested Pueblo dances, reformers would have received different reasons for opposing the dances than they expected. Among the Hopi, opposition to the dances derived from two diverse groups - older members of the tribe who considered themselves "traditional," and some younger Hopis who had attended boarding school and converted to Christianity. Many of the older Hopi witnesses explained their decision to testify against the dances as a wish to fulfill a Hopi prophecy. For example, several years before the compilation of the Secret Dance File, the Hopi Masawistiwa wrote a letter to the Commissioner of Indian Affairs in which he complained about the immorality of the dances. Masawistiwa explained that "the idea of reporting these matters to the Commissioner did not originate with me. Since the creation of the world, according to the traditions held by the Hopis, a revelation of these things was so ordained." 67

Although the Hopi witnesses in the Secret Dance File agreed with the moral reformers that Hopi dances were immoral, they often fixed the blame for this alleged immorality on different parties than did the moral reformers. The reformers faulted "traditional Hopis" and vehemently opposed the dances because of their concern that federal boarding school education for Indian children would be a waste of money if the children were then reexposed to traditional dances. However, many Hopi witnesses believed that boarding school 
students were the cause, not the victims, of the sexual immorality of the dances. Judge Hooker Hongeva contended that "the returned students are the backbone of these immoralities. They have gone off to school and learned enough of the white man's ways to give them a puffed-up mind, or the 'big head,' and they come back and plunge into these ways, with adultery as their bait, and become leaders in these gross wrong things." ${ }^{68}$ To at least some Hopis who opposed the dances, boarding school education, not tribal tradition, was to blame for the supposed immorality in Hopi dances.

In New Mexico, opposition to the dances developed mainly among some Pueblo Indians who had spent long years in boarding school away from their pueblos. Often their opposition to the dances went hand-in-hand with their rejection of other aspects of Pueblo life. Many chose to wear Western dress and objected to working on their pueblo's communal irrigation ditch. Their refusal to conform to Pueblo norms often elicited beatings and severe punishment from their tribal councils. However, these Pueblos did not seem to disapprove of the dances as sexually immoral. Instead, they had more "practical" reasons for opposing the dances, believing that they interfered with work and impeded the progress of the pueblo. Taos Indian Joe Lujan told reformers who interviewed him that "the only thing is that [the dances] interfere with the progress of the children. I don't know of any immorality connected with them." 69

Pueblo Indians who defended their dancing also denied any sexual immorality in their dances or in their culture. Turning the tables on moral reformers, many Pueblo Indians contended that it was really white dances that were sexually illicit. As Martin Vigil of Tesuque Pueblo told an interviewer, "our dances are not wicked like you people.... You come down to any Pueblo, visit our dances, we don't hug each other when we dance.... We dance about five feet apart, not like you people." ${ }^{\circ}$ Ritual clowns in Pueblo dances often used their performances to comically illustrate Vigil's point. Some of the clowns' performances can best be seen, in fact, not as a reflection of either the immorality or liberated quality of everyday Pueblo life, but as a parody of white behavior. Historically, Pueblo clowns had used their performances to "transform what might have been unique and disruptive historical events into a part of the ongoing, internal, cultural dialogue of the people. ... They make fun of outsiders, thereby reinforcing the community's own sense of self-worth and cultural continuity." 71 Fergusson once observed that the clowns "seem to embody the Indian's real attitude toward whites. The white man is usually the butt of the joke." ${ }^{2}$ In some of the clown's skits, what moral reformers (and, to some extent, new feminists) thought they were seeing-reflections of actual Pueblo sexuality—was actually a mirror held up for them to view how the Pueblos represented white sexuality. 
The clowns used their acts to parody whites in all their interactions with the Pueblos. At San Ildefonso Pueblo, one of the clowns

made a specialty of tourists. With parasol and handbag, [he poked] his way around the Indians like a member of the Podunk Woman's Club, gathering material for a lecture on aborigines. He patted the babies, fingered the women's jewelry, asked embarrassingly intimate questions, and made explanatory remarks over his shoulder." She says she does bathe her baby every day. ... Yes, she wears underwear." ${ }^{\prime 3}$

The clowns also mocked white sexual behavior, even their dances. Pueblo observations of white dances and loosening sexual mores often became fodder for Pueblo clowns. Writer Elizabeth DeHuff figured out that a group of small Indian boys who were dressed in the "cast-off garments of white neighbors" performed in a "dance closely related to the 'Charleston," " and DeHuff recognized the popular tune they sang. ${ }^{74}$

The Pueblos even ridiculed the peculiar desire of whites to pry into other people's sexuality. The scene Bentley described in her testimony for the Secret Dance File can be interpreted as the Pueblos' pointed parody of white sexual politics. Two clowns dressed as women in very short skirts entered the dance plaza. Male clowns pretended to try to pull their skirts down, but then stooped and look under their skirts. ${ }^{75}$ This skit possibly served both to spoof new sexual mores in white culture (as expressed in dress) and to critique the moral reformers' obsession with finding and rooting out sexual impropriety. Though claiming to be repulsed and shocked by the alleged sexual immorality of Pueblo dances, moral reformers seemed to take a voyeuristic interest in attending the dances and in collecting ever more testimony about them. This phenomenon was not lost upon the Indians.

The clowns' mocking of white behavior served many purposes: to temporarily overturn power relationships between whites and Indians, to critique white culture, and to differentiate Pueblo from white culture. Pueblos had become increasingly dependent on whites for their economic livelihoods in the 1920s, and the government had succeeded in forcing many of their children into schools. Moral reformers repeatedly stressed that Indian cultures were inferior to white civilization. Overpowered by whites in many aspects of their lives, some of the clowns' performances offered the Pueblos a much needed opportunity to symbolically reverse hierarchies, to feel powerful over and superior to whites. Some anthropologists have argued that, in general, the clowns' skits and antics created a carnival-like occasion in which the social order was turned upside down. ${ }^{76}$ At the same time, the clowns' parody of white behavior provided 
another lesson in how good Pueblos should not behave. ${ }^{77}$ Given that some Pueblos had become interested in adopting white ways, the clowns may have ridiculed white lifestyles in order to deter young Indians from choosing to abandon Pueblo ways. Presenting whites in the clowns' skits as the virtual opposite of Pueblo Indians served to fortify the boundary between Pueblo and white society. ${ }^{78}$

As they did in white women's debates over the dances, Pueblo women played an important symbolic role in Indian debates. Unlike white women, however, Pueblo men on both sides of the debate insisted on the "modesty" of their women. They often contrasted their women's respectable behavior with that of supposedly immodest white women. Hopi Otto Lomavitu, a contributor to the Secret Dance File, wrote to the editor of the Flagstaff, Arizona, newspaper, "I wish to say that I am proud of my poor benight [ sic] people that though they lack education, they have enough decency to mark out a woman clothed in nudity, ever admiring herself in a glass, twisting her head like a reptile, ever powdering her nose and painting her lips and eyelids, as absolute shamelessness."79

The two Indian sides in the dance controversy, however, presented competing visions of Pueblo women in the realm of the gendered division of labor. As white women had superimposed their view of "new womanhood" on to Pueblo women, Pueblo Indian men also invoked Pueblo women to symbolize their opposing positions regarding Indianness and progress. The dispute in the late I920s at Santa Clara Pueblo illustrates this point. When representatives from both the "progressive" and "conservative" parties in the pueblo met with Assistant Commissioner of Indian Affairs Edgar Merritt to resolve their differences over who should govern the pueblo, the issue of whether Pueblo women should work only in the home or still participate in the customary cleaning of the entire village proved particularly contentious. Desiderio Naranjo, the governor from the Progressive Party, listed as one of his grievances the way in which the village was cleaned:

Now according to the regulation of this village, sweeping the village is just once a year.... What we don't agree with us is for all to get out, women, children; the men are sweeping the village and the women carrying the dirt out on their backs and that doesn't suit us very well. It may be all right a hundred years ago the time when we didn't have no wagons or teams to throw the trash out. But now we have teams and wagons to haul the trash out of the village. It is not necessary for the women to get out and sweep the village, they have plenty to do at home.

In contrast, Juan Jose Gutierrez, governor for the Conservative Party, insisted that women should still dispose of the trash in the village. ${ }^{80}$ 
The BIA had also bound Indian women's domesticity in the home to the notion of Indian "progress." Not surprisingly, therefore, Merritt agreed with Naranjo, using the occasion to preach, "We men in America pride ourselves upon our generosity to our women folks. It is said that the American husband is the best husband in the world because he is always generous to his wife and children and he protects them in every way possible. I am sure that you want to be just as good to your women folks as any other man in America." Merritt ruled that on cleaning days, the women be required to work in their homes, but not to haul the trash away. ${ }^{81}$

Since Pueblo custom designated certain men as their pueblos' representative to the outside world, Pueblo women themselves seem not to have participated in the dance controversy. Nevertheless, autobiographies by two Hopi women-Polingaysi Qoyawayma and Helen Sekaquaptewa-provide some clues as to how some Pueblo women may have reacted to their depictions in the dance controversy. Qoyawayma and Sekaquaptewa reinforced Pueblo men's view of Pueblo women as modest. In her as-told-to autobiography, Qoyawayma, for example, indicted the BIA for their violation of Hopi sexual codes:

Worst of all [the injustices whites had done to them], she had seen women stripped and marched through a dipping vat like so many cattle, becauseso the white man claimed - an epidemic threatened the reservation residents. This was a thing no Hopi woman could forgive. Children may run naked, but grown girls and women are modest. To force the exposure of their bodies in this way had been unthinkable. ${ }^{82}$

Qoyawayma strongly countered white women's images of Pueblo culture and womanhood. Known first as Bessie and then as Elizabeth Ruth by white missionaries, Qoyawayma refused to play the role of victim of Indian male lust assigned to her by some moral reformers (as well as some Hopi witnesses). Inspector Sweet and other moral reformers used Elizabeth Ruth/Qoyawayma as an example to prove their claim that the Hopis were licentious and that Indian women were victims in need of rescue. Sweet wrote,

Elizabeth Ruth and Minnie Jenkins are fine types of Indian young womanhood ... lifted from an otherwise unspeakable life ... but they must make their home with the missionary and his family, for the reason that their chastity would have utterly no protection in an Indian village where ... promiscuous adulterers . . . are allowed to run at large after night. ${ }^{83}$

In her autobiography, however, Elizabeth Ruth/Qoyawayma explained her move to the home of the missionaries in quite different terms. Miserable at home because her parents refused to convert to Christianity and to adopt the 
American customs she had learned at boarding school, Qoyawayma claimed she had moved to the missionary's home to be in a more hospitable environment in which her views were accepted and in which she could enjoy modern conveniences. Instead of conceiving of herself as the moral reformers did, as an object to be rescued from an "unspeakable life," Qoyawayma framed herself as the active subject who consciously chose to move to the missionary's home. ${ }^{84}$ As Qoyawayma represented herself, she did not abandon Hopi ways in her early life because she found her old life "immoral." Rather, she wanted what she believed whites had: "abundant supplies of food, good clothing, and opportunities to travel." 85

Sekaquaptewa and Qoyawayma also rejected the notion of new feminists that Indian women were victimized by the BIA and moral reformers. New feminists were fond of charging the Indian Bureau with forcing Indian children to go to boarding school. But Sekaquaptewa, after ten years at Keams Canyon Boarding School, wished to continue her schooling. Because she was still a minor, she needed her parents' permission to attend an off-reservation school. She managed to cajole BIA officials into letting her attend Phoenix Indian School for three years without her parents' permission. Qoyawayma ventured down the mesa to the newly opened Keams Canyon School to enroll herself. As described in her autobiography, "No one had forced her to do this thing. She had come down the trail of her own free will." She also hid herself in a wagon bound for Sherman Institute in Riverside, California, an Indian boarding school, and would not get out until her parents signed a paper allowing her to go. ${ }^{86}$ Qoyawayma and Sekaquaptewa proved unwilling to accept the role of victim. Although they did not participate directly in the dance controversy, their autobiographies indirectly countered white women's images of Indian women as either sexually immoral or liberated.

Who won the dance controversy? True declared victory at the Los Angeles meeting, believing she had participated "in forming and conducting a small world court in which paganism was tried and found wanting." 87 The GFWC did not pass a resolution calling for the preservation of Indian dances and postponed the election of the Indian Welfare Committee chair. ${ }^{88}$ Yet defenders of Indian dances seem to have won the larger dance controversy. After publishing a debate between Austin and reformer Flora Seymour in Forum, the editors received many more letters favoring the preservation of Indian dances. ${ }^{89}$ Atwood won back her position as chair of the Indian Welfare Committee. In 1925, in a case brought against the governor and council of Taos for allegedly beating two returned Indian students who did not wish to wear Indian costume 
during a dance, the judge found that the Pueblos should be allowed to regulate their own affairs..$^{90}$ Although the BIA continued to use Circular 1665 to suppress native religion among some tribes, by the late 1920 s the issue of Indian dances had all but faded from public debate. ${ }^{9 \mathrm{I}}$

At the same time, it is not clear who "won" the subtextual battle over white sexual mores. True believed that "pagan" sexual immorality with all of its parallels to emerging modern sexual mores in America had been convicted and given a death sentence at the GFWC meeting. She may have been right. Though the dance controversy was settled in favor of the Pueblos, those who defended the dances at the GFWC meeting did so on the terms of moral reformers. No one stood up to defend Pueblo dances on the grounds that the Pueblo had more "natural" sexual standards than white Americans. Instead, Lummis's elevation of the Pueblos as the epitome of "Home" and "Religion" - values moral reformers had long upheld-became the major argument in favor of the dances. By the late I920s, new feminists seem to have adopted Lummis's position. Their uncertainty about emerging sexual mores led them to transform Pueblo women from models for new women to preservers of tradition.

As for the Pueblos, both those who opposed and those who defended the dances actually benefited from the dance controversy. Both sides learned to use white women's interest in their affairs for their own purposes. Pueblo Indians who opposed the dances turned the moral reformers concern into a vehicle through which they made known their other grievances and through which they also articulated their vision for the future of Indian-white interaction. To some extent, they diverted the moral reformers from their original purposes. What moral reformers initiated as a campaign to eradicate the "immoral" dances of the pueblos evolved instead into a defense of those Indians who did not wish to dance or to clean their pueblo's community irrigation ditch. After the dance controversy died down, the Progressive Pueblo Council and their primary white sponsor, Clara True, sought to challenge the existing leadership structures among the pueblos, calling essentially for a separation of civil from religious affairs by disempowering the religious leader of each pueblo, the cacique. ${ }^{92}$

Indians who defended their dances realized that their white allies in the dance controversy could help further their primary interests - the return of land and water rights..$^{93}$ During the dance controversy, new white activists had developed images of profoundly religious traditional Pueblo Indians who had kept pure their ancient, nature-based creed against all odds. In their portrayal of the Pueblos, the new activists privileged religion as a defining characteristic of Pueblo life over other cultural, social, and economic traits. In subsequent years, the Pueblo Indians, particularly those at Taos Pueblo, turned this white portrayal 
to work for them in their battles to regain some of their original use-areas. If claims to the land based on precontact sovereignty had little impact in courts, perhaps claims based on the sacredness of certain land sites and on religious freedom would resonate among white activists and policymakers. As Sylvia Rodriguez has pointed out, by using the emerging white romantic view of them in the I920s, Taos Pueblo eventually regained the Blue Lake area in the mountains above the pueblo-land they had once used freely. ${ }^{94}$

Pueblos who defended their dances did not realize all of their goals, however. Although they equated the perpetuation of their dances with the maintenance of autonomy and the prevention of integration into white culture, their dire economic straits forced them to develop some means of earning income. Increasingly, the Pueblos commercialized their public dances as well as their traditional crafts. In essence, they marketed their ethnic identity for tourists in order to cope with the exigencies of dependency. This strategy threatened to corrode the very cultural boundary they sought to strengthen.

The controversy over Indian dances in the 1920 seems in its simplest terms to have been a battle between assimilationists and cultural preservationists over Indian religion. But a deeper reading of the controversy yields insight into a myriad of other issues. The controversy reveals how white women attempted to make sense of rapidly changing sexual mores in their own society. It also illuminates how Pueblo Indians coped with increasing acculturation pressures. Finally, it illustrates how Indian women came to serve as powerful symbols of both tradition and change for all parties in the controversy. These issues all become interwoven in the scene Bentley recounted in the Secret Dance File. Here Bentley expressed her shock that Hopi clowns looked up the skirts of women. Bentley's testimony fueled female moral reformers' attempts to restrict Pueblo Indian dancing, an effort that seemed to become necessary to them only when they sensed that sexual mores were spinning out of control in white society. Other white women - new feminists - opposed efforts to ban Pueblo dancing, discovering in the Pueblos a society that embodied their emerging ideals of women's sexual expressiveness and sexual control. Pueblo men, who enacted this skit, seemed to have actually designed it not to reflect their own society but to comment upon and ridicule white sexual mores. Pueblo women, depicted by male clowns in the dance, became 1920s-style "new women," at once reviled, revered, and ridiculed.

\section{Notes}

I. Statement of Evelyn Bentley, September 30, 1920, E. M. Sweet, Jr., collection, National Anthropological Archives, Smithsonian Institution, Washington, D.C. The Pueblos include both the Hopis of Arizona and all of the Pueblo peoples of 
New Mexico. Even though all of these groups are considered Pueblos, there are many significant differences of language, religion, social structure, and ceremonial cycle between the Hopi and the Rio Grande Pueblos and among the Rio Grande Pueblos. See Edward Dozier, The Pueblo Indians of North America (New York: Holt, Rinehart, and Winston, 1970). The only other historical article I know of that has drawn upon the so-called Secret Dance File (the Sweet collection) is Martin Bauml Duberman, "Documents in Hopi Indian Sexuality: Imperialism, Culture, and Resistance," Radical History Review 20 (spring/summer 1979): 99-130. This article reprints some of the affidavits in the Secret Dance File but provides little analysis.

2. John Collier, who became Commissioner of Indian Affairs under Franklin Roosevelt in 1933, railed against the Secret Dance File as "subterranean propaganda." See "For two years, the public has heard," n.t. (1923), and John Collier, letter to the editor, New York Times, November 14, 1924, carton I, "Collier, Pueblos and Religious Persecution," California League of American Indian (CLAI) Papers, Bancroft Library, Berkeley, California.

3. Circular 1665, John Collier papers (Sanford, N.C.: Microfilming Corporation of America, 1980), reel 5 .

4. Circular 1665 and supplement, Collier papers, reel 5 .

5. Mary Austin, Land of Journey's Ending (New York: The Century Company, 1924), 444. These new Indian advocacy organizations included the American Indian Defense Association (AIDA), the New Mexico Association on Indian Affairs (NMAIA), the Eastern Association on Indian Affairs (EAIA), and the Indian Welfare committee of the General Federation of Women's Clubs (GFWC).

6. Lawrence C. Kelly, The Assault on Assimilation: John Collier and the Origins of Indian Policy Reform (Albuquerque: University of New Mexico Press, 1983), 298339; Kenneth Philp, John Collier's Crusade for Indian Reform (Tucson: University of Arizona Press, 1977), 57-65; and David M. Strausfeld, "Reformers in Conflict: The Pueblo Dance Controversy," in The Aggressions of Civilization: Federal Indian Policy Since the I880s, ed. Sandra Cadwalader and Vine Deloria, Jr. (Philadelphia: Temple University Press, 1984), 19-43.

7. Paula S. Fass, The Damned and the Beautiful: American Youth in the Igros (New York: Oxford University Press, 1977); Paul Robinson, The Modernization of Sex: Havelock Ellis, Alfred Kinsey, William Masters and Virginia Johnson (New York: Harper \& Row, 1976), I-4I; Elaine Tyler May, Great Expectations: Marriage and Divorce in Post-Victorian America (Chicago: University of Chicago Press, 1980); Peter Gabriel Filene, Him/Her/Self: Sex Roles in Modern America (New York: Harcourt, Brace, Jovanovich, 1974), I-I68; Ellen K. Rothman, Hands and Hearts: A History of Courtship in America (New York: Basic Books, 1984), I79-3II; John D'Emilio and Estelle Freedman, Intimate Matters: A History of Sexuality in America (New York: Harper \& Row, 1988), I7I-274; William L. O'Neill, Divorce in the Progressive Era (New Haven: Yale University Press, 1967); Kathy Peiss, Cheap Amusements: Working Women and Leisure in Turn-of-the-Century New York (Philadelphia: Temple University Press, 1986), especially 163-84; Ruth Rosen, The Lost Sisterhood: Prostitution in America, 1900-1918 
(Baltimore: Johns Hopkins University Press, 1982); and Carroll Smith-Rosenberg, "The New Woman as Androgyne: Social Disorder and Gender Crisis, 1870-1936," in Disorderly Conduct: Visions of Gender in Victorian America, ed. Carroll SmithRosenberg (New York: Alfred Knopf, 1985), 245-96.

8. While historians Joan Wallach Scott and Carroll Smith-Rosenberg have argued in several essays about ways in which discourses use gender, sexuality, and the body as metaphors for other political and economic conflicts, this article argues that the reverse can be true as well. Discourses about other conflicts can also be used for debating matters of gender and sexuality. See Scott, "Gender: A Useful Category of Historical Analysis," in Gender and the Politics of History, ed. Joan Wallach Scott (New York: Columbia University Press, 1988), 28-52; and Smith-Rosenberg, "Hearing Women's Words: A Feminist Reconstruction of History," in Disorderly Conduct, II-52.

9. Many anthropologists have observed that the Pueblos customarily designated certain men as the spokesmen of their pueblos to outsiders. See Alice Marriott, Maria: The Potter of San Ildefonso (Norman: University of Oklahoma Press, 1948), II9. On the differences between men's and women's roles, see M. Jane Young, "Women, Reproduction, and Religion in Western Puebloan Society," Journal of American Folklore 100 (October-December 1987); and Alice Schlegel, "Male and Female in Hopi Thought and Action," in Sexual Stratification: A Cross-Cultural View, ed. Alice Schlegel (New York: Columbia University Press, 1977).

Io. Mary Dissette to Miss Willard, March 3, 1924, Indian Rights Association (IRA) papers (Glen Rock, N.J.: Microfilming Corporation of America, 1975), reel 40.

II. Amelia Stone Quinton, "Care of the Indian," in Woman's Work in America, ed. Annie Nathan Meyer (New York: Henry Holt and Company, I89I), 373-9I; Valerie Sherer Mathes, "Nineteenth Century Women and Reform: The Women's National Indian Association, American Indian Quarterly I4:I (1990), 3-18; Helen Wanken, "Woman's Sphere and Indian Reform: The Women's National Indian Association, 1879-190I" (Ph.D. diss., Marquette University, 198I), 7-38; and Peggy Pascoe, Relations of Rescue: The Search for Female Moral Authority in the American West, I8741939 (New York: Oxford University Press, 1990), 7-10.

I2. Frederick Hoxie, "The Curious Story of Reformers and the American Indians," in Indians in American History, ed. Frederick Hoxie (Arlington Heights, Ill.: Harlan Davidson, 1988), 213; Brian Dippie, The Vanishing American: White Attitudes and United States Indian Policy (Middletown, Conn.: Wesleyan University Press, 1982), I08-II, I6I-76; Francis Paul Prucha, "Indian Policy Reform and American Protestantism, I880-1900," in People of the Plains and Mountains: Essays in the History of the West, ed. Ray Allen Billington (Westport, Conn.: Greenwood Press, 1973), I2629, 134-39; Lisa Emmerich, "'To respect and love and seek the ways of white women': Field Matrons, the Office of Indian Affairs, and Civilization Policy, I8901938” (Ph.D. diss., University of Maryland, 1987), I2-13; and Francis Paul Prucha, American Indian Policy in Crisis: Christian Reformers and the Indian, I865-1900 (Norman: University of Oklahoma Press, 1976), 169-40I. 
13. Quoted in Emmerich, “'To respect and love," 24. See also, Helen Bannan, "True Womanhood" on the Reservation: Field Matrons in the U.S. Indian Service, Southwest Institute for Research on Women, Working Paper no. I8 (Tucson: Women's Studies, 1984), 5-6; and Emmerich, "'To repect and love," " I6-36.

I4. Dissette to Herbert Welsh, June I8, I894, Dissette to Mrs. Miller, March I4, I894, and Dissette to "Friend," April 7, I894, IRA papers, reel II; Dissette to Welsh, February 5, I896, and Dissette to D. R. James, June 4, I895, IRA papers, reel I2; Dissette to Welsh, April 25, I898, IRA papers, reel 13; and Dissette to Miss Willard, March 3, 1924, IRA papers, reel 40.

15. See Record Group (RG) 75, Pueblo Records, Superintendent's Correspondence with Day School Employees (entry 40), box 5, Paguate I9I4 folder, and box 8, Santo Domingo I9I4 folders, National Archives and Records Administration (NARA), Rocky Mountain Branch, Denver; "Dissette Collection of Indian Photographs," El Palacio 5I (March 1944): 60; and Fred Kabotie with Bill Belknap, Fred Kabotie: Hopi Indian Artist (Flagstaff: Museum of Arizona Press, 1977), 29. Dissette died in 1944.

I6. Clara True to Matthew Sniffen, January 29, I9I2, IRA papers, reel 25; True to Samuel Brosius, March 22, I913, IRA papers, reel 27; True to Welsh, April 19, I922, IRA papers, reel 38; True to Sniffen, June 16, 1919, IRA papers, reel 34; "History of Schools in Santa Clara," Collier papers, reel 29; and True to Superintendent Crandall, August 29, 1902, RG 75, Pueblo Records, entry 38, box I, NARA, Denver. During her time at Morongo, True oversaw the legendary hunt for "Willie Boy," an Indian man accused of killing his Indian lover and her father. A recent book explores this incident. See James A. Sandos and Larry E. Burgess, The Hunt for Willie Boy: Indian-Hating and Popular Culture (Norman: University of Oklahoma Press, 1994). A movie made about the incident, "Tell Them Willie Boy is Here," made True into a "leggy and handsome" emancipated new woman who had a torrid affair with the character played by Robert Redford (Sandos and Burgess, Hunt for Willie Boy, 57, 66). See also Harry Lawton, Willie Boy: A Desert Manhunt (Balboa Island, Calif: Paisano Press, 1960). For more on both Dissette and True, see Margaret Jacobs, "Uplifting Cultures: Encounters Between White Women and Pueblo Indians, I890-1935" (Ph.D. diss., University of California, Davis, I996), chap. 2.

17. Mathes, "Nineteenth Century Women," I-3; and Wanken, "Woman's Sphere," 7-I2.

I8. See Jacobs, "Uplifting Cultures," chap. 2.

19. Robert M. Utley, The Indian Frontier of the American West, 1846-1890 (Albuquerque: University of New Mexico Press, 1984), 220, 243. The Ghost Dance movement, which started among the Paiutes in Nevada, promised that God would kill off all the whites, bring dead Indians back to life, and return the earth to the Indians. Philip Weeks, Farewell, My Nation: The American Indian and the United States, 1820-1890 (Arlington Heights, Ill.: Harlan Davidson, Inc., 1990), I09-92, 232; and Hazel Hertzberg, The Search for an American Indian Identity: Modern Pan-Indian Movements (Syracuse: Syracuse University Press, 1971), I0-I4. A circular issued by Commissioner of Indian Affairs W. A. Jones in 1902, entitled "Long 
Hair Prohibited," mentioned briefly at the end that Indian dances should be prohibited. This circular, however, did not specify which dances it found in need of prohibition, and it did not mention sexual immorality as a justification for banning Indian dances. See Circular 13, January 1920, Special Collections, Knight Library, University of Oregon, Eugene. Thanks to Annette Reed-Crum for bringing this document to my attention.

20. Superintendent, Santa Fe Indian School, "Memorandum for Supervisor Rosenkranz," December 26, 1913, RG 75, Santa Fe Indian School Day School Correspondence, I9I3-I9I4 (entry 42), box 2, folder "S," NARA, Denver; and Commissioner Price to Pedro Sanchez, U.S. Indian Agent, Pueblo Agency, June 27, I883, RG 75, Northern Pueblos, Misc. Reports and Correspondence, 1868-1934, box 5, folder I03, NARA, Denver. In The Pueblo Indians of North America, Dozier writes that up until 1900 , Protestant missionaries did not "apparently object to the ceremonies of the pueblos" (I05-6). I do not find evidence of concern about Pueblo dances on the part of missionaries until I9I5.

2I. "Exhibit D," Sweet collection.

22. Rosendo Vargas to Santa Fe Indian School, November 20, 1915, enclosed in Frederic Snyder to Superintendent Lonergan, Pueblo Day Schools, November 23, 1915, RG 75, Southern Pueblos Agency, General Correspondence Files, I9II-1935 (entry 90), box 21, folder 070, NARA, Denver.

23. Dissette to Brosius, April I8, I9I3, IRA papers, reel 27; Dissette to Brosius, December 3, I9I0, and True to Brosius, December I, I9IO, IRA papers, reel 23; and True to Sniffen, June 2, I919, and True to Brosius, October 18, I919, IRA papers, reel 34.

24. For some of the publicity that reformers wrote in condemnation of the dances, see Flora Seymour, "The Delusion of the Sentimentalists," Forum 7I (March 1924): 273-80; William E. Johnson, "Those Sacred Indian Ceremonials," The Native American 24 (20 September 1924): 173-77; William E. Johnson, "Civilizing Indian Dances and White Writers," typewritten ms., carton I, "Pueblo Indian Religious Persecution Re. 'Pussyfoot'" folder, CLAI papers; Herbert Welsh, letters to the editor of The Herald and New York Times, August 22 and October 15, 1924, and "Indian Dances Degrading, Says Y.W.C.A. Leader," New York Times, November 25, 1923, clippings in Collier papers, reel 9; Hubert Work, "Our American Indians," The Saturday Evening Post, May 31, 1924, p. 92; and letter from Secretary of the Interior Work to San Ildefonso Pueblo, reprinted in Indian Truth I (March 1924): 4, Indian Truth I (April 1924): 4, and Indian Truth I (June 1924): I-2. Indian Truth was an official publication of the Indian Rights Association. See also, G. E. E. Lindquist, The Red Man in the United States: An Intimate Study of the Social, Economic and Religious Life of the American Indian (New York: George H. Doran Co., 1923), 68, 267-68, 273, 287. This book published the results of an American Indian Survey begun in 1919 by the Interchurch World Movement.

25. Circular 1665 and supplement, Collier papers, reel 5.

26. Pascoe, Relations of Rescue, 32-69.

27. Circular 1665 and supplement, Collier papers, reel 5. 
28. Peiss, Cheap Amusements, 163-84.

29. Filene, Him/Her/Self, 303 .

30. Katsinas (more commonly spelled "kachinas") are supernatural beings who live in sacred areas near some of the pueblos. They visit the pueblos at certain times of year for religious ceremonies. According to Frederick J. Dockstader, in The Kachina and the White Man: The Influences of White Culture on the Hopi Kachina Religion (Albuquerque: University of New Mexico Press, 1985), "these beings have the power to bring rain, exercise control over the weather, help in many of the everyday activities of the villages, punish offenders of ceremonial or social laws, and in general act as a link between gods and mortals" (9). What anthropologists have called the "kachina cult" is strongest among the Hopi and Zuni, takes a modified form among the Rio Grande Pueblos, and seems to fade out among the northeasternmost pueblos of Taos and Picuris. Kachinas also refer to the masked impersonators of the supernatural beings who perform at some Pueblo ceremonies. Sometimes the kachinas entertain the crowd alongside the clowns. Dolls representing the masked impersonators of the spirits have become a major tourist item for sale in the Southwest. See also, Alfonso Ortiz, The Tewa World: Space, Time, Being, and Becoming in a Pueblo Society (Chicago: University of Chicago Press, 1969), I8; and Fred Eggan, "Pueblos: Introduction," in Handbook of North American Indians, vol. 9, ed. Alfonso Ortiz (Washington, D.C.: Smithsonian Institution, 1979), 227-30.

3I. Statement of Johnson Tuwaletstiwa, August 14, I920, Sweet collection.

32. Statement of Kuwanwikvaya, August 26, 1920, Sweet collection.

33. Statement of Tuwaletstiwa, August I4, 1920. See also, Statement of Mango, August I2, I920, both in the Sweet collection.

34. Statement of Tuwaletstiwa, August I4, 1920. See also Statement of Talasnimtiwa, August 12, 1920, both in the Sweet collection.

35. Statement of Tuwaletstiwa, August I4, 1920, Sweet collection.

36. On female moral reformers' views of Indian women as victims, see Pascoe, Relations of Rescue, Bannan, "True Womanhood"; and Emmerich, "To respect and love." Kathy Peiss and Christina Simmons argue that before the I920s, middleclass white women contrasted their own "purity" with other "subordinate groups," whom they "depicted as loose, rowdy, carnal, and debased." See "Passion and Power: An Introduction," in Passion and Power: Sexuality in History, ed. Kathy Peiss and Christina Simmons (Philadelphia: Temple University Press, 1989), 3-13. While this may have been true of their depictions of working-class women and black women, interestingly white middle-class women did not seem to "sexualize" Indian women until the i920s.

37. Dissette to Willard, March 3, I924, IRA papers, reel 40.

38. Dissette to Williard, March 3, 1924.

39. Filene, $\mathrm{Him} / \mathrm{Her} / \mathrm{Self}$, I65.

40. Statement of Quoyawyma, April 16, 1921, Sweet collection.

4I. Dissette to Willard, March 3, I924, IRA papers, reel 40. In this period, sexologist Havelock Ellis, Judge Ben Lindsey, and anthropologist Elsie Clews Parsons all had 
advocated the notion of "trial marriage," a "legal marriage with birth control and with the right to divorce by mutual consent for a childless couple." See Robinson, The Modernization of Sex, 30; Filene, Him/Her/Self, 70, 166; Fass, The Damned, 260-90; and Rosemary Lévy Zumwalt, Wealth and Rebellion: Elsie Clews Parsons, Anthropologist and Folklorist (Urbana: University of Illinois Press, 1992), 46. Parsons, a "new feminist" and an anthropologist who studied the Pueblos, was also a defender of their dances.

42. May, Great Expections, 2; Filene, Him/Her/Self, 42-44; O'Neill, Divorce in the Progressive Era, 3, 31, 33-63; and Pascoe, Relations of Rescue, 37.

43. D'Emilio and Freedman, Intimate Matters, 204-15, 233-34.

44. Filene, Him/Her/Self, I49-50. See also, Joanne J. Meyerowitz, Women Adrift: Independent Wage Earners in Chicago, 1880-1930 (Chicago: University of Chicago Press, 1988); and Regina Kunzel, Fallen Women, Problem Girls: Unmarried Mothers and the Professionalization of Social Work, I890-1945 (New Haven: Yale University Press, 1993).

45. Quoted in Fass, The Damned, 23.

46. Quoted in Stanley Coben, The Rebellion Against Victorianism: The Impetus for Cultural Change in rg20s America (New York: Oxford University Press, 1991), 76. During this time period, social commentators also linked jazz dancing to the spread of black culture, which they deemed another type of "savagery." Thanks to an anonymous reader at Frontiers for pointing this out. See also David Levering Lewis, When Harlem Was in Vogue (New York: Oxford University Press, 1979, 1981).

47. Stella Atwood speech, June I0, 1924, at I7th Biennial Convention, General Federation of Women's Clubs, Los Angeles, GFWC papers, archives, GFWC International, Washington, D.C. Atwood once wrote to Mabel Dodge Luhan that she was a conservative and was not always comfortable with the radicalism of those she worked with in Indian affairs. See Atwood to Mabel Dodge Sterne [Luhan], December 2I, 1922, Mabel Dodge Luhan papers, Beinecke Rare Book and Manuscript Library, Yale University.

48. Statement of "The American Indian Policies Association" (later the AIDA), February I4, I923, box 2A, Amelia E. White papers, School of American Research, Santa Fe, New Mexico.

49. Erna Fergusson, Dancing Gods: Indian Ceremonials of New Mexico and Arizona (New York: Alfred Knopf, I93I), xiv.

50. Austin, Land of Journey's Ending, 258.

5I. On explanations of Pueblo clowning as a fertility rite, see Alfonso Ortiz, "Ritual Drama and the Pueblo World View," in New Perspectives on the Pueblo, ed. Alfonso Ortiz (Albuquerque: University of New Mexico Press, 1972), I52; Barbara Babcock, "Arrange Me Into Disorder: Fragments and Reflections on Ritual Clowning," in Rite, Drama Festival, Spectacle: Rehearsals Toward a Theory of Cultural Performance, ed. John J. MacAloon (Philadelphia: Institute for the Study of Human Issues, 1984), II2; Dozier, The Pueblo Indians, I5I; Young," Women, Reproduction, and Religion," 436-38; and Emory Sekaquaptewa, "One More 
Smile for a Hopi Clown," in The South Corner of Time: Hopi, Navajo, Papago, Yaqui Tribal Literature, ed. Larry Evers (Tucson: Sun Tracks, 1980), 14-17. For explanations of clowns as a means of social control, see Vera Laski, Seeking Life, memoirs of the American Folklore Society, vol. 50. (Philadelphia: American Folklore Society, 1958), 13-14; and Dozier, The Pueblo Indians, 157-58.

52. Austin, Land of Journey's Ending, 255-56.

53. Fergusson, Dancing Gods, xv.

54. Elsie Clews Parsons, "Waiyautitsa of Zuni, New Mexico," in Pueblo Mothers and Children: Essays by Elsie Clews Parsons, 1915-1924, ed. Barbara Babcock (Santa Fe: Ancient City Press, 1991), 95.

55. Fergusson, Dancing Gods, 39. Among the Pueblos, there are many dances in which male clowns impersonate women. There are also some dances- the Deer Dance, Corn Dance, Rainbow Dance - in which women themselves dance. Furthermore, there are a few dances in which female clowns perform burlesques and parodies, particularly of the Navajos. Among the Hopi and at San Ildefonso and Santo Domingo pueblos, there are even dances in which women parody men of their pueblo. See Schlegel, "Male and Female" 257; Charlotte J. Frisbie, "Epilogue," in Southwestern Indian Ritual Drama, ed. Charlotte Frisbie (Albuquerque: University of New Mexico Press, 1980), 319-20; and Donald N. Brown, "Dance as Experience: The Deer Dance of Picuris Pueblo," in Frisbie, Southwestern Indian Ritual Drama, 7I-92.

56. Parsons, "The Zuni La'mana," in Pueblo Mothers and Children, 43.

57. Mabel Dodge Luhan, Movers and Shakers, vol. 3, Intimate Memories (1936; reprint, Albuquerque: University of New Mexico, 1985), 375.

58. Christina Simmons, "Modern Sexuality and the Myth of Victorian Repression," in Peiss and Simmons, Passion and Power, 158, I64, I69-70; and Estelle Freedman, "'Uncontrolled Desires': The Response to the Sexual Psychopath, 1920-1960," in Peiss and Simmons, Passion and Power, 199-225. Freedman argues that women paid a high price "for recognition of their sexual desire and the removal of female purity as a restraint on male sexuality" (212). Women who were victims of rape or sexual assault were thereafter portrayed as willing participants. Pamela Haag makes a complimentary point, arguing that the so-called sexual liberalization that occurred in the 1920 s was still based on older gendered assumptions that associated men with self-mastery and rationality and women with irrationality. In this scenario, women were still not in control of their sexuality. See "In Search of 'The Real Thing': Ideologies of Love, Modern Romance, and Women's Sexual Subjectivity in the United States, 1920-40," Journal of the History of Sexuality 2:4 (1992): 547-77.

59. Luhan to Elizabeth Shepley Sergeant, June IO, [1925], Collier papers, reel 5.

6o. Mabel Dodge Luhan, Edge of Taos Desert: An Escape to Reality (New York: Harcourt, Brace, and Company, 1937), 179.

6I. See Indian Truth I (June 1924): 2, 6; telegram and letter from Sniffen to True, May 24, 1924, and Brosius to Sniffen, May 29, 1924, IRA papers, reel 40; and True to Sniffen, July I and 23, I924, IRA papers, reel 4I. Of Spanish descent, Nina Otero 
married Captain Warren of the U.S. Army in 1904. In addition to working as an inspector for the BIA, she was the chair of the New Mexico Federation of Women's Clubs, the state chair of the women's Republican organization, and from 1917 to 1929 the county superintendent of schools in Santa Fe County. During the I930s, she directed the literacy project for the Works Progress Administration (WPA). See Women of New Mexico collection, box 2, folder 40, Center for Southwest Research, General Library, University of New Mexico; Ruth Laughlin, Caballeros, 2d. ed. (Caldwell, Idaho: Caxton Printers, 1945), 393; and Charlotte Whaley, Nina Otero-Warren of Santa Fe (Albuquerque: University of New Mexico Press, 1994).

62. True to Sniffen, July I, I924, and telegrams from True to Sniffen, June 9 and Io, I924, IRA papers, reel 4I.

63. Charles Lummis, "To the Women of the United States in Biennial Convention Assembled," June 6, 1924, Indian Defense Association of Central and Northern California, private collection of Michael Harrison, Sacramento. Lummis often repeated this sentiment. For just a few examples, see Mesa, Cañon and Pueblo (New York: Century Company, 1925), I58; and Lummis's typewritten letter to the editor of the New York Times, September 18, 1924, CLAI papers.

64. See, for example, True to Brosius, October 28 and November 27, I929, IRA papers, reel 45; True to Sniffen, January I2, 1928, IRA papers, reel 44; and Seymour, "Delusion of the Sentimentalists.”

65. See, for example, Mary Austin, "The Folly of the Officials," Forum 7r (March 1924): 28I-88; Elizabeth Shepley Sergeant, "The Principales Speak," New Republic 33 (7 February 1923): 273-75; and John Collier, “Do Indians Have Rights of Conscience?” Christian Century (12 March 1924): 346-49, clipping in Collier papers, reel ro.

66. "Transcript of Proceedings of All-Pueblo Council," Santo Domingo Pueblo, October 6, 1926, Collier papers, reel 8.

67. Statement of Masawistiwa, December II, I920, Sweet collection. See also, statements of Judge Hooker Hongeva, December 9, 1920; Salako, December 9, 1920; Siventiwa, December I0, 1920; and Kuwanwikvaya, August 26, 1920, Sweet collection. In Religion and Hopi Life in the Twentieth Century (Bloomington: Indiana University Press, I99I), John Loftin argues similarly that Hopi "Friendlies," who supported cooperation with whites, based their actions on what they believed to be Hopi prophecy (xix-xxi, 78).

68. Statement of Hongeva, December 9, 1920, Sweet collection.

69. Statement of Joe Lujan, May I5, I924, IRA papers, reel 40. For more on the beatings and punishment meted out to Indians who wore western clothing or refused to dance, see Statement of Don Mondragon, May I4, 1924, IRA papers, reel 40; Rosendo Vargas to Santa Fe Indian School, November 20, 1915, enclosed in Frederic Snyder to Superintendent Lonergan, Pueblo Day Schools, November 23, 1915, RG 75, entry 90, box 2I, folder 070, NARA, Denver; and Emory Marks to Superintendent Crandall, September 26, 1924, and affidavits from Joe Sandoval, April 1925, and John Gomez, April 9, 1925, RG 75, Northern Pueblos General Correspondence Files, 1912-1938, box I7, folder 070, NARA, Denver. 
70. Interview with Martin Vigil, December ı0, 1970, Doris Duke American Indian Oral History Project, box 19, folder 754, and January 26, 1971, box 19, folder 764, Center for Southwest Research, General Library, University of New Mexico.

71. Alfonso Ortiz, "Indian/White Relations: A View from the Other Side of the 'Frontier,'” in Indians in American History, ed. Frederick Hoxie (Arlington Heights, Ill.: Harlan Davidson, 1988), I2. Alison Freese's "Send in the Clowns: An Ethnohistorical Analysis of the Sacred Clowns' Role in Cultural Boundary Maintenance Among the Pueblo Indians" (Ph.D. diss., University of New Mexico, I99I), also looks at the role of clowns in dealing with Catholicism, the Spanish, and the first white anthropologists. See also Jill Drayson Sweet, "Burlesquing 'the Other' in Pueblo Performances," Annals of Tourism Research I6 (1989): 62-75.

72. Erna Fergusson, "Laughing Priests," Theatre Arts Monthly I7 (August 1933): 662.

73. Fergusson, "Laughing Priests," 658.

74. Quoted in Mary Roberts Coolidge, The Rain Makers: Indians of Arizona and New Mexico (Boston: Houghton Mifflin Company, 1929), I68.

75. Statement of Bentley, September 30, 1920, Sweet collection.

76. Louis Hieb explains that the "ritual clowns turn the world topsy-turvy, and their behavior is often described as involving inversion and reversal." See his "Meaning and Mismeaning: Toward an Understanding of the Ritual Clown," in Ortiz, New Perspectives on the Pueblo, I64. See also Dockstader, The Kachina, 26. The clown performances often involved sex role and status reversals. See Ortiz, "Ritual Drama," I48-49; Schlegel, "Male and Female," 257; and Dozier, The Pueblo Indians, 157, 203. For the ways in which scholars have analyzed European carnivals as occasions for temporarily reversing hierarchies, see M. M. Bakhtin, Dialogic Imagination: Four Essays by M. M. Bakhtin, ed. Michael Holquist (Austin: University of Texas Press, 198I); and Terry Castle, Masquerade and Civilization: The Carnivalesque in Eighteenth-Century English Culture and Fiction (Palo Alto: Stanford University Press, 1986). For more on the function of "symbolic inversion," see Barbara A. Babcock, ed., The Reversible World: Symbolic Inversion in Art and Society (Ithaca: Cornell University Press, 1978). In Reversible World, "Arrange Me Into Disorder," and "'A Tolerated Margin of Mess': The Trickster and His Tales Reconsidered," Journal of Folklore Research II:3 (1975): I47-86, Babcock argues that symbolic inversion such as that of Pueblo clowns cannot be understood simply as a "steam valve," that is, as an outlet for otherwise inappropriate behavior. She argues instead that the ambiguity and paradox inherent in symbolic inversion serves as a means of promoting creativity. In Babcock's view, clowns do not just promote conformity to social norms but also "prompt speculation about, reflection on, and reconsideration of the order of things" ("Arrange," I22).

77. Sam Gill has noted that one function of the clowns is to "act Kahopi, that is nonHopi," thereby teaching the distinctions between Hopi and non-Hopi behavior (Beyond 'The Primitive': The Religions of Nonliterate Peoples [Englewood Cliffs, N.J.: Prentice-Hall, 1982], 95). See also, Hieb, "Meaning and Mismeaning"; and Ortiz, "Ritual Drama." Joann W. Kealiinohomoku argues that Hopi clowns actually 
administer a dose of Hopi-style "medicine" to cure inappropriate behavior. Thus kahopi clowning cures kahopi behavior among the Hopi. See her article, "The Drama of the Hopi Ogres," in Frisbie, Southwestern Indian Ritual Drama, 58, 64.

78. For more on boundary maintenance as a way of understanding cultural difference, see Fredrik Barth, ed., Ethnic Groups and Boundaries: The Social Organization of Culture Difference (Boston: Little, Brown, \& Company, 1969); and Sylvia Rodriguez, "Land, Water, and Ethnic Identity in Taos," in Land, Water, and Culture: New Perspectives on Hispanic Land Grants, ed. Charles L. Briggs and John R. Van Ness (Albuquerque: University of New Mexico Press, 1987). For a critique of this concept, see Bonnie TuSmith, "Ethnicity and Community," in All My Relatives: Community in Contemporary Ethnic American Literatures, ed. Bonnie TuSmith (Ann Arbor: University of Michigan Press, 1993), 6-24.

79. Otto Lomavitu to Editor, Cococino Sun, Flagstaff, Ariz., August 29, 1923, clipping in carton I, "Indian Religious Persecution Correspondence" folder, CLAI papers.

8o. Proceedings of Council of Santa Clara Indians with Assistant Commissioner E. B. Merritt, October 22, 1927, Collier papers, reel 29. In 1924, the Progressive Party held its own election. The Conservative Party boycotted the election and chose their own governor so that the pueblo then had two governors. See Indian Truth 2 (January 1925): 3; Edward Dozier, "Factionalism at Santa Clara Pueblo," Ethnology 5 (April 1966), 172-85, which describes the genesis and development of the conflict in this pueblo between 1894 and 1935; and True to Sniffen and to Edgar Merritt, both letters, January 2, I928, IRA papers, reel 44; True to Brosius, May 5 and October 28, 1929, IRA papers, reel 45. Factionalism became even more complicated at Santa Clara in the I930s when both the Progressive and Conservative parties divided into two wings. See Dozier, "Factionalism"; and Elizabeth Shepley Sergeant, "Memorandum on the Santa Clara Situation," Summer 1935, Collier papers, reel 29.

8I. Proceedings of Council of Santa Clara Indians with Assistant Commissioner E. B. Merritt, October 22, 1927, Collier papers, reel 29.

82. Polingaysi Qoyawayma [Elizabeth Q. White], No Turning Back: A True Account of a Hopi Indian Girl's Struggle to Bridge the Gap Between the World of Her People and the World of the White Man, as told to Vada Carlson (Albuquerque: University of New Mexico Press, 1964), I06; Helen Sekaquaptewa, Me and Mine: The Life Story of Helen Sekaquaptewa, as told to Louise Udall (Tucson: University of Arizona Press, I969).

83. E. M. Sweet to William Layne, February 6, 1921, Sweet collection.

84. Qoyawayma, No Turning Back, 74-75, 79-80.

85. Qoyawayma, No Turning Back, 49.

86. Sekaquaptewa, Me and Mine, 91-92, 132-33; and Qoyawayma, No Turning Back, 22-26, 52-54.

87. True to Sniffen, July I, I924, IRA papers, reel 4 I.

88. Telegrams from True to Sniffen, June 13 and June 23, I924, IRA papers, reel 4I. 
89. Seymour, "The Delusion of the Sentimentalists"; Austin, "The Folly of the Officials"; and Hazel Hertzberg, The Search for an American Indian Identity: Modern Pan-Indian Movements (Syracuse: Syracuse University Press, I97I), 205.

90. "Pueblos Have Right to Run Own Affairs, Court Decides," Santa Fe New Mexican, August 15, 1925, clipping from Ina Sizer Cassidy papers, Laboratory of Anthropology/Museum of Indian Arts and Culture, Santa Fe, New Mexico.

91. On the BIA's suppression of a northern California tribe in the late I920s and beyond, see Annette Reed-Crum, “Tolowa 'Hush': Native Response to Circular I665" (paper presented at 35th annual conference of the Western History Association, Denver, Colo., October II-I4, I995).

92. True to Brosius, December 16, 1926, and True to Welsh, December 17, 1926, IRA papers, reel 43; True to Sniffen, January 2, I928, True to Merritt, Assistant Commissioner of Indian Affairs, January 2, 1928, and True to Sniffen, January I2, I928, IRA papers, reel 44; and True to Brosius, November 27, I929, IRA papers, reel 45. See also, Sniffen, letter to the editor, New York Times, written November I, 1924, in Collier papers, reel 9; and Kate Leah Cotharin, chair of the Indian Committee for the Women's Auxiliary to the National Council of the Protestant Episcopal Church, letter to the editor, The Independent II6 (May I, I926): 53I-32.

93. The papers of the Southwest Association on Indian Affairs (formerly the New Mexico Association on Indian Affairs, or NMAIA) at the New Mexico State Records Center contain a folder no. IO9 of Indian correspondence, 1922-1923. Many Pueblos wrote letters to the NMAIA asking for help in procuring more land or protecting their existing land and water rights. These letters also request assistance in preventing the excavation of burial sites. The minutes of the NMAIA's meetings (folder no. 37) also reveal the way in which Indians made use of the new activists for their own agendas.

94. Sylvia Rodriguez, "Art, Tourism, and Race Relations in Taos: Toward a Sociology of the Art Colony," Journal of Anthropological Research 45:I (1989): 77-99, and "Land, Water, and Ethnic Identity in Taos," 352. For another account of Taos Pueblo's attempt to recover Blue Lake, see R. C. Gordon-McCutchan, The Taos Indians and the Battle for Blue Lake (Santa Fe: Red Crane Books, I99I). Sam Gill also points out that Indians put the white view of them as "at one with nature" to work for them in battles to regain land (Mother Earth: An American Story [Chicago: University of Chicago Press, 1987], I30, I4I, I45). In recent years, by arguing that the land is sacred to them, the Hopi have also tried to stop the expansion of the Snow Bowl ski area on the San Francisco Peaks near Flagstaff, Arizona. Like Taos Pueblo, the Hopis may have found that this argument is more effective than other rationales to prevent development of their prior use-areas. See Loftin, Religion and Hopi Life, 9I. 